\title{
Trouble Among Colonial Birds at Isle of Bays
}

\author{
by Fred G. Bard, Regina
}

In late May, 1962, Fred Lahrman and $I$ went to the Isle of Bays in Old Wives Lake, southwest of Moose Jaw, to see how the colonial birds were making out; for with the dry weather of recent years the level of the water in the lake was getting rather low. Although there were perhaps $10 \%$ fewer birds than in 1961 they were beginning to nest and seemed to be doing well. The White Pelicans, for instance, were established in three areas of the island. The main concentration with about one thousand nests was in the rocky southeast end of the island. The two smaller concentrations of the pelican, with 350 and 40 nests respectively, were located in the northwest part of the island.

Since both Mr. C. S. Brown and Mr. R. G. Young of the Department of Natural Resources, Saskatchewan, wanted to see this area, Mr. Lahrman and I returned to the island in early July. There had been good rains; we knew from our earlier trip that there were many White Pelicans, Double-crested Cormorants, Ringbilled Gulls, Californian Gulls and Common Terns so it was with a real feeling of pride that I looked forward to showing them this most important bird sanctuary in the settled part of Saskatchewan. As we approached the island, however, we realized that something was wrong; there were very few birds on the island or in the sky.

An examination of the island revealed the dead bodies of thousands of young pelicans and Ring-billed Gulls. Some had apparently been dead for less than a week, but most of them had been dead for two or three weeks. In the main colony where there had been a thousand nests in May, there were only 75 live young pelicans. In the larger of the two small colonies at the northwest end of the island we counted 100 live young pelicans and 287 dead ones. There were about 300 young Ringbilled Gulls, but we saw no evidence

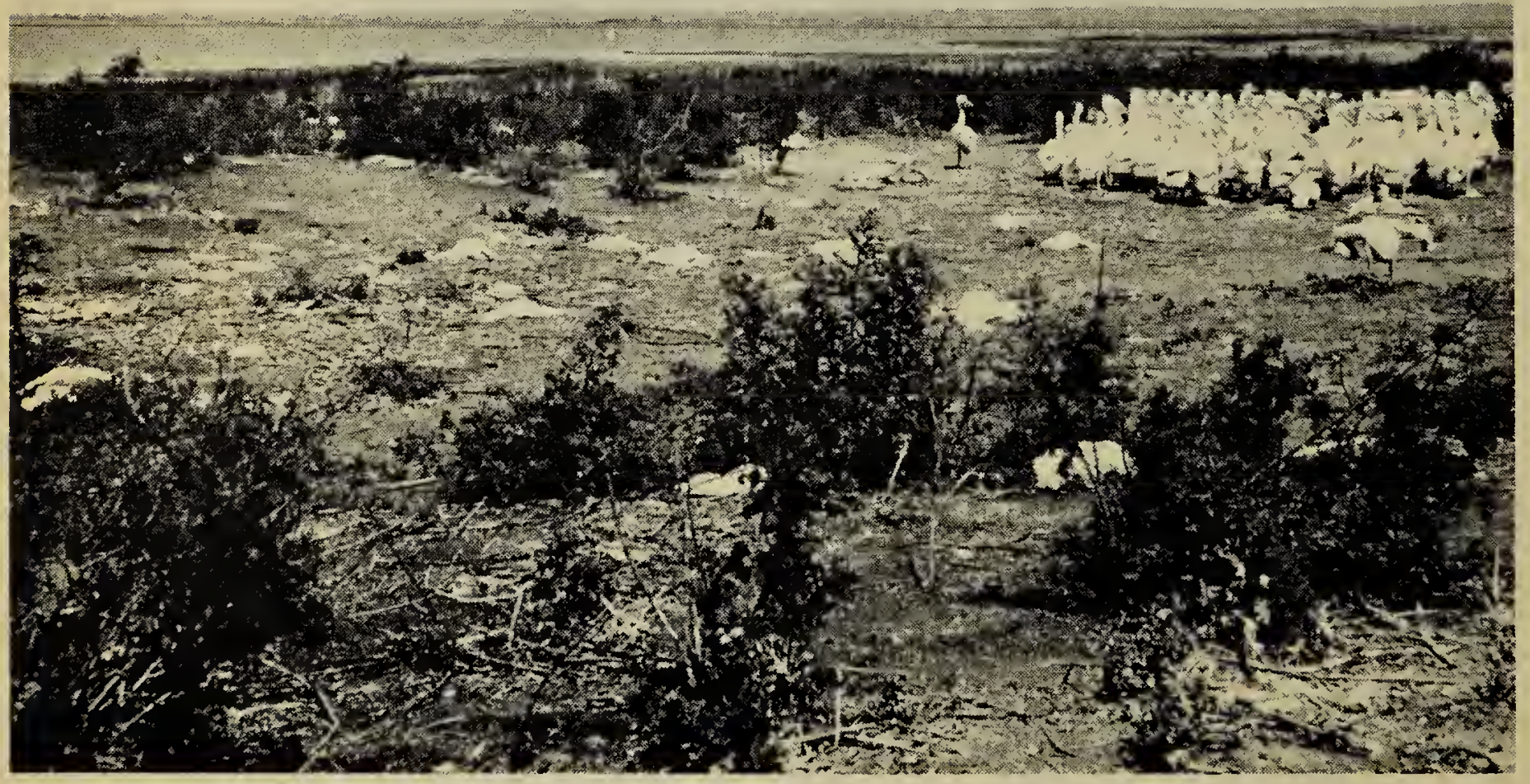

Phato by Fred G. Bard White Pelican colony site at Isle of Bays, July 11, 1962, showing many dead young pelicans. 


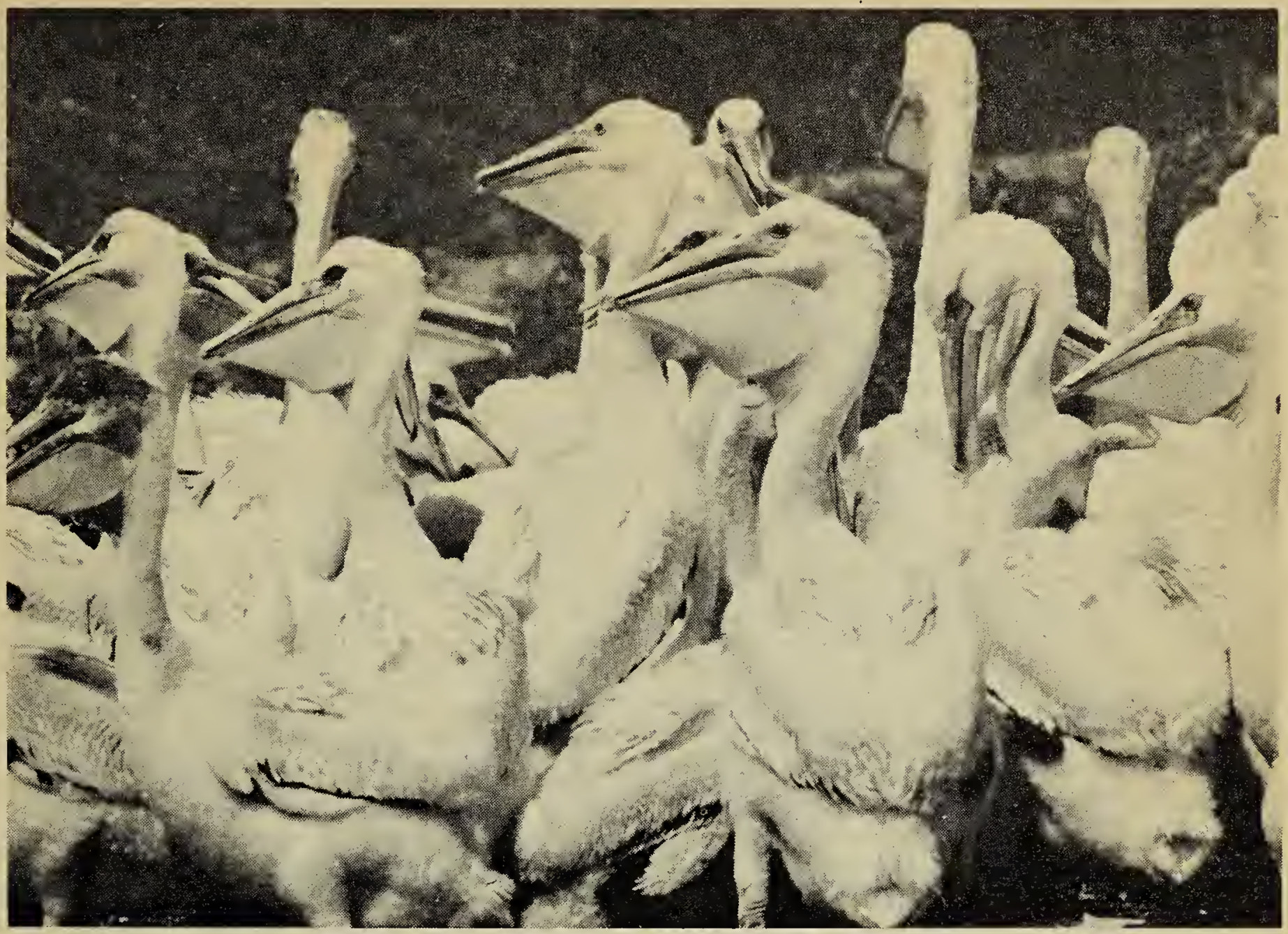

Photo by Fred G. Bard The living young White Pelicans at Isle of Bays, Old Wives Lake, July 11, 1962, appear healthy.

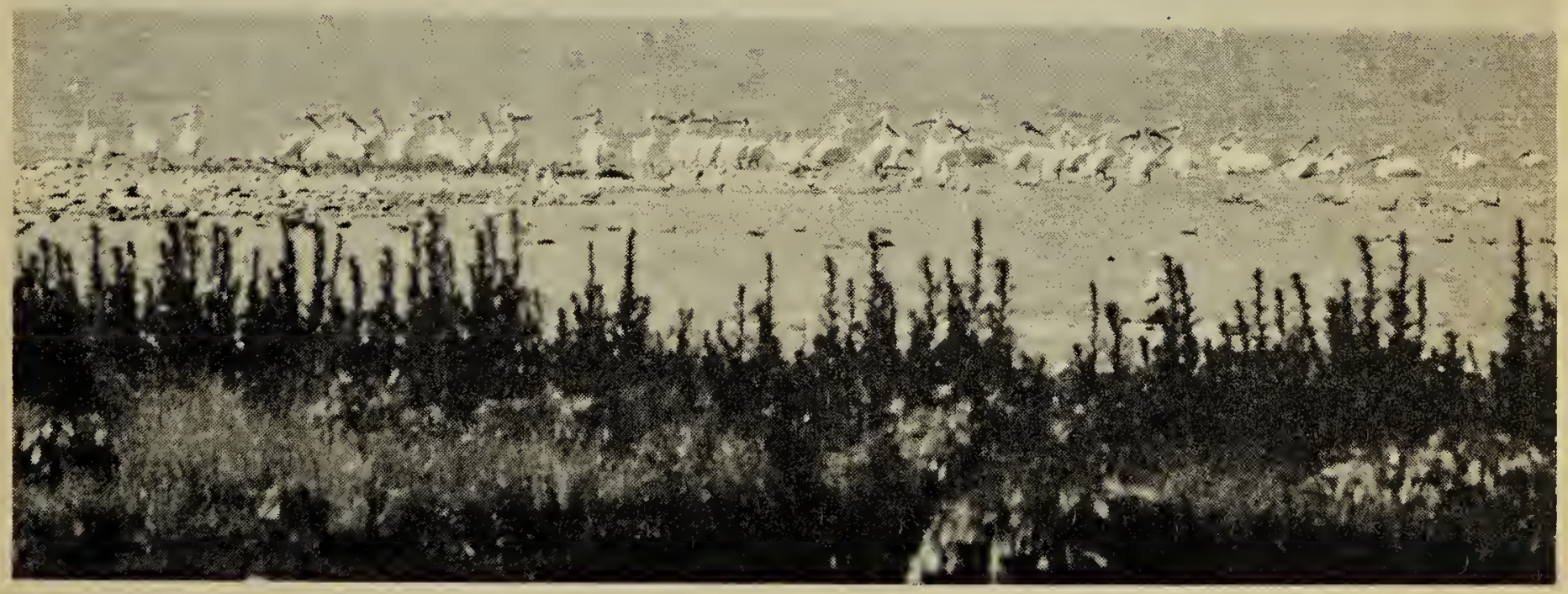

Adult White Pelicans at Isle of Bays, July 11, 1962, waitina for our departure so they can return to the colony. 
at all of young Double-crested Cormorants, Californian Gulls or Common Terns. During our time on or hear the island we saw only fifteen cormorants, three Californian Gulls and one lone Common Tern.

We were unable to draw any conclusions about the causes of death. The weather had been good and there were no reports of hail storms in the area so weather does not seem to have been a factor. It is perhaps significant that the dead birds were nearly all young birds. There were only eight dead adult pelicans and ten dead Ring-billed Gulls found on the island.

It is worth noting that numbers of gulls were reported dead in the fields around Mortlach. This report came from Fred Lahrman's family who farm in that area. We would like to know if others noted dead gulls in the fields this year. Please send reports to the museum or to the Blue Jay editor.

Mr. W. H. Horner, Deputy Minister of Agriculture, Saskatchewan, reported that he had visited a gull colony near Penzance and had seen numbers of young birds, both Ringbilled Gulls and Common Tern, dead. Please send us the information if you know of excessive losses among any colonial birds.

During the summer several reports of pelicans being found dead or near dead have come in to the museum. There have been at least fifteen such birds in the Qu'Appelle Lakes. There are, of course, a few reports of such birds every year. The cause of death is not known, and it is not known if an exceptionally large number of adult pelicans have been dying this year.

Dr. Stuart Houston in his article "Hazards faced by colonial birds" (Blue Jay, June, 1962) considers the Isle of Bays in Old Wives Lake the only "safe" place for colonial birds in southern Saskatchewan. Our observations this year indicate that colonial birds even here may suffer very severe losses. We will watch the colonial birds more closely in 1963 and hope that their troubles do not recur. We would be interested in other observations and suggestions regarding colonial birds.

\section{HAZARDS FACED BY COLONIAL BIRDS}

In response to Dr. Stuart Houston's article of the above title in the Blue Jay, June. 1962. pp. 74-77, David Stirling, Victoria, B.C., wrote to suggest that a "NO LANDING" law would discourage visits by most people and would thus help to reduce human disturbance of colonial birds.

Mr. David Stirling of the Parks Branch, Department of Recreation and Conservation, British Columbia government, says that the disturbance of colonial birds is becoming a real problem on the West Coast. He enclosed a printed information sheet which his department distributes to sightseers who visit bird colonies. The information sheet is as follows:

\section{HOW TO VISIT A SEA BIRD COLONY}

Well meaning but uninformed people, naturalists included, can seriously damage bird colonies simply by visiting them. Because of disturbance, a number of dangers confront the birds. Disturbed birds may fail to breed, desert their nests, or even kill their young. Eggs and young left unattended may be eaten by predators, or damaged by heat or cold. Frightened young gulls may fall into crevices, or lose touch with their parents. Unattended cormorant nests are particularly vulnerable to crow predation.
When in or near a bird colony, observe these rules:

(1) Never take a dog into a colony.

(2) Move quietly and slowly; allow time for the birds to "get ready." On the other hand, keep moving; you are keeping birds from their nests.

(3) Watch where you step.

(4) Large groups of people should never enter a colony. Small groups should remain fairly compact to reduce the area of disturbance. One or two may sit quietly in a colony if they are more or less hidden. Larger groups can rarely do this effectively.

(5) Don't stop for long discussions, or picnics, while conspicuously in or near a colony. Stay in the colony a much shorter time than you would like to.

Well meaning people, even naturalists, can cause more damage to a bird colony than would a party of egg smashers. Obey these rules, and the damage you will do will be minimal.

Dept. of Recreation and Conservation British Columbia 